\title{
ОСОБЛИВОСТІ ПІСЛЯДИПЛОМНОї ОСВІТИ КРАїН ПОСТРАДЯНСЬКОГО ПРОСТОРУ
}

\author{
Львівський національний медичний університет імені Данила Галицького, м. Львів, Україна
}

\begin{abstract}
Мета: аналіз особливостей становлення медичної та фрармацевтичної післядипломної освіти в країнах пострадянського простору.

Матеріали і методи. У роботі проведено ретроспективний аналіз розвитку післядипломної освіти в пострадянському просторі. Для розбору використано аналітико-описовий метод вивчення й узагальнення теорії та досвіду навчання у вищих навчальних закладах, критичний аналіз наукової літератури з педагогіки та методики навчання за темою дослідження.

Результати. У роботі окреслено основні етапи розвитку післядипломної освіти у пострадянських країнах, висвітлено різницю післядипломної медичної освіти Росії та інших держав на сьогодні та проведено порівняння їх з міжнародними та європейськими моделями. Відображено, що післядипломна медична та фрармацевтична освіта у пострадянських республіках перебуває в стані розбудови та реформування.

Висновки. У розробці нових систем-моделей післядипломної освіти не достатньо враховано національні особливості та традиції країн пострадянського простору та використано далеко не всі можливості загальноприйнятих стандартизованих європейських і світових моделей безперервної медичної та фрармацевтичної освіти.
\end{abstract}

КЛЮчОВІ СЛОВА: післядипломна медична освіта; пострадянські країни; європейські моделі освіти; підвищення кваліфрікації.

Підвищення кваліфрікації спеціалістів у всі часи вважалось одним із невідкладних завдань. Особливо це стосується медичних спеціальностей, які потребують продовження навчання протягом усієї профресійної діяльності. Завершивши навчання у медичному вищому навчальному закладі, лікар поінформований про ті методи лікування і той перелік лікарських засобів, які використовували в практичній медицині на момент його навчання. Однак вже через 5-7 років ці знання стають не актуальні, їх недостатньо для підтримки профресійних компетентностей. Тому післядипломна медична та фрармацевтична освіта - це не виправлення помилок додипломної освіти, а формування інтегрованого міждисциплінарного бачення професійних навичок, в основі якого лежить навчальний процес, який повинен базуватися на передачі найновішої медико-фрармацевтичної інорормації, яка необхідна практичній охороні здоров'я для надання медичної допомоги.

Поглиблювати медичну освіту та зробити її неперервною - завдання та проблема була та $\epsilon$ актуальною у всі часи. Зрозуміло, що рівень освітньої діяльності, фрорми і методи навчання, структура та зміст необхідної інорормації безперервно змінюються, реагуючи на потреби суспільства.

Тому аналіз розвитку післядипломної освіти в пострадянському просторі, структуризація всіх фрактів (факторів) дасть нам можливість в подальшому не допускати помилок і знаходити (c) О.Є. Січкоріз, 2018 більш вдалі шляхи вирішення наявних проблем безперервної сучасної медичної освіти.

Мета дослідження: аналіз особливостей становлення медичної та фрармацевтичної післядипломної освіти в країнах пострадянського простору.

Матеріали і методи. У роботі проведено ретроспективний аналіз розвитку післядипломної освіти в пострадянському просторі. Для розбору використано аналітико-описовий метод вивчення й узагальнення теорії та досвіду навчання у вищих навчальних закладах, критичний аналіз наукової літератури з педагогіки та методики навчання за темою дослідження.

Результати дослідження та їх обговорення. Післядипломна освіта в колишньому Радянському Союзі бере свій початок у Царській Росії 3 кінця XIX сторіччя (у 1885 р.), де за ініціативою княгині Олени Павлівни в Санкт-Петербурзі був заснований Клінічний інститут удосконалення лікарів (нині Санкт-Петербурзька академія післядипломної освіти). До 1918 р. він був єдиним центром післядипломної освіти. Другим став Київський (1918), далі Одеський та Казанський (1927), Московський (1930), Мінський (1931), Ташкентський (1932), Тбіліський та Бакинський (1935). До 1970 р. була сорормована структуризована система спеціалізації та удосконалення лікарів та провізорів і прийнята єдина система післядипломної освіти, де навчання відповідало певному стандарту, а посвідчення, отримане в результаті спеціалізації чи удосконалення, ставало «конвертованим» на всій території СРСР. Медична післядипломна освіта як 
єдина державна система фрункціонує починаючи 3 1964 р. У 1965 р. всі інститути удосконалення лікарів були передані Мінздраву (МО3) СРСР, з 1968 р. вперше запроваджена інтернатура.

Після розпаду СРСР підвідомчі Міністерству охорони здоров'я СРСР державні інститути удосконалення лікарів перейшли під юрисдикцію урядів своїх суверенних держав, де одні залишилися інститутами, інші реорганізувалися в академії або національні інститути, але мета діяльності залишилася та ж сама - забезпечення післядипломної безперервної медичної освіти [7].

Наше завдання: висвітлити різницю післядипломної медичної освіти Росії та інших держав на сьогодні та порівняти їх з міжнародними та європейськими моделями.

Післядипломна медична освіта у Російській Федерації

У Росії до цього часу функціонує та ж сама система післядипломної освіти, яка була створена в радянські часи. Тоді як у Росії таке навчання продовжується один рік (інтернатура), що звичайно ж $є$ недостатнім. Натомість в розвинутих країнах навчання лікаря-спеціаліста після закінчення вищого навчального закладу, у так званій резидентурі, триває від 4,5 до 7 років. Разом із тим, у засобах масової інфрормації ректор Нижньогородської академії запропонував із 2017 р. у країні зовсім відмінити інтернатуру. Він стверджує, що для того, щоб розпочати свій професійний шлях у поліклініках достатньо отримати диплом про закінчення вищого навчального закладу. Таким чином, російські лікарі зможуть «підійти до тіла» хворого, навчаючись в 2 рази менше ніж, наприклад, американський лікар. 3 гонором ректор заявляє « ... нет повода для тревоги, так как небольшие сроки обучения никогда не мешали нашим врачам быть лучшими». Практичним навичкам студент повинен навчитись у стінах рідного вищого навчального закладу, знову ж таки доводить ректор академії [12].

Чи можна все ж таки без підвищення медичної кваліфікації, а зразу ж із студентської лави стати таким же кардіохірургом, яким стає американець або голландець за 7 років підготовки? - запитуємо ми себе. Але і це ще не все. Канадський або бельгійський хірург, так само, як і сімейний лікар, отримавши ліцензію, безперервно навчається, періодично проходить переекзаменування для підтвердження спеціальності. У Росії лікарю потрібно всього лише раз на 5 років пройти «підвищення кваліфікації» в повному відриві від практичної роботи (в медичному ВН3), скласти іспит та отримати або підтвердити кваліфікаційну категорію (вищу, першу або другу). Така фрорма післядипломної освіти знову ж таки повертає лікаря на рівень школярства, що є, на нашу думку, абсолютно недостатньо [3, 19].
Без сумніву, російська вища школа має розвинуту інфраструктуру та володіє потужним науково-педагогічним потенціалом, однак рівень підготовки медичних кадрів та їх кваліфікація $€$ недостатньою. Основна причина такого стану справ $€$ відсутність сучасної моделі безперервної медичної освіти лікарів на основі системного фрормування професійних компетенцій і стимулів, які визначають мотивацію лікарів до розвитку профресійних кваліфікацій, ігнорування післядипломної підготовки лікарів, яке і так залишилось на рівні початку XX століття. Мінздрав (МО3) Росії, ігноруючи повністю досягнення сучасної медичної освіти в світі, заспокоює критиків тим, що медичні інститути переходять на новий освітній стандарт, у результаті якого практична підготовка випускників медичних вищих навчальних закладів радикально буде змінена.

На нашу думку, вперше враховано вимоги Європейського відділу Всесвітньої організації сімейних лікарів, які стали його обов'язковим компонентом. У документі підкреслюється орієнтація сімейної медицини на пацієнта, його сім'ю, передбачається особливий процес проведення консультування, тривалість і неперервність надання медичної допомоги, виділяється процес прийняття рішень $з$ профрілактики розвитку хвороб, технології ранньої діагностики, лікування розповсюджених хвороб, невідкладної медичної допомоги на основі доказової медицини з врахуванням фрізичних, психологічних, соціальних, культурних, побутових аспектів. Головним аспектом діяльності лікаря загальної лікарської практики стає особистісно-орієнтований підхід, велику увагу в ньому приділяється відносинам лікар-пацієнт, сучасним науковим особливостям прийняття рішень, інтегрованому аналізу проблеми індивіда. Такого фрахівця готують в процесі післявузівської освіти: післядипломна освіта і неперервна професійна освіта $[4,5]$.

Підготовка медичних кадрів у Республіці Білорусь

Організатори безперервної медичної освіти в Республіці Білорусь вважають, що вони проживають в європейській країні і тому медична освіта повинна бути невід'ємною складовою європейської та світової науки. Підвищення кваліфікації спеціалістів із вищою медичною та фрармацевтичною освітою в Республіці Білорусь передбачає такі форми: перепідготовку, підвищення кваліфікації, стажування. Вони здійснюються у Білоруській медичній академії післядипломної освіти та у Вітебському державному медичному університеті. Перепідготовка, тобто отримання додаткової медичної освіти на базі вищої медичної освіти, здійснюється із 60 спеціальностей. Тривалість складає 16 тижнів (4 місяці) (600-612 навчальних годин). Для громадян Білорусі вона 
$€$ безкоштовною, для іноземців платною - від 1000 до 2500 доларів США залежно від профрілю (хірургічний, стоматологічний, терапевтичний) і назви спеціальності. Документом, який підтверджує присвоєння кваліфікації після проходження перепідготовки, є диплом державного зразка. Рівень підготовки білоруських лікарів є високий як у теоретичному плані, так і в плані практичних навичок. Підвищення кваліфрікації має обов'язковий, регулярний характер і здійснюється з метою підвищення професійної майстерності медичних та фрармацевтичних кадрів. Цикли підвищення кваліфрікації тривають від одного тижня до одного місяця (40-160 навчальних годин). Для практичного засвоєння лікарями-спеціалістами нових клінічних методів та технологій організовують стажування на робочому місці [9]. Відмінно організована саме практична підготовка слухачів ВН3, які навчаються передовим, сучасним медичним технологіям (органна та клітинна трансплантологія, неонатологія та дитяча реаніматологія, нові високотехнологічні та ефективні втручання в травматології, ортопедії, хірургії, офтальмології та багатьох інших галузях медичної науки і практики). Білоруські вчені, які навчають практичних лікарів, постійно підвищують свій професійний рівень: відвідують європейські та світові наукові форуми, проходять стажування та опановують найсучасніші технології практично в будь-якій державі Європи. Проводять Інтернет-конференції за участю провідних європейських наукових медичних центрів. Постійно оновлюють інфрормацію на Інтернет-сайті Білоруської медичної академії післядипломної освіти, яка необхідна для самопідготовки лікарів. Це сучасна наукова продукція у вигляді: монографій, навчальних посібників, навчально-методичних розробок викладачів кафедр академії, публікацій в наукових фрахових журналах. Оволодіння професійними навичками надання першої медичної допомоги лікарі-слухачі проходять в навчально-тренувальному центрі швидкої медичної допомоги, який оснащений унікальним обладнанням виробництва Норвегії - манекенами-тренажерами, навчальними деорібриляторами та ін. [6]. Разом із тим, необхідно відзначити, що Республіка Білорусь - практично єдина держава Європи, яка не долучилась до Болонського процесу.

Власне такий підхід до післядипломної освіти забезпечує високу якість надання медичної допомоги в країні. Разом із тим, післядипломна освіта в країні має також невирішені проблеми і перебуває в стані реформування, однак все здійснюється на державному рівні і тому будь-яка реорганізація забезпечує високоякісну медичну допомогу [16].

Післядипломна медична освіта у Вірменії

У цих колишніх республіках СРСР система безперервної медичної освіти лікарів продовжується за старою радянською схемою та базується на одноразовому проходженні циклу удосконалення, що дозволяє лікареві претендувати на отримання (підтвердження) категорії або ліцензії після проходження одного циклу тематичного удосконалення із спеціальності (156 год) протягом 5 років. На сьогодні у Республіці Вірменія система для кредитування безперервної медичної освіти складається із 4 категорій. В кожній категорії $€$ певна кількість одиниць (кредитів), котрі набираються лікарем як у процесі проходження циклів із акредитованих програм (категорія I), так і в ході наукової діяльності - захисту кандидатських і докторських дисертаційних робіт (категорія II), публікації тез доповідей і статей в журналах, монографій і методичних рекомендацій (категорія III), участі у наукових симпозіумах і конференціях (категорія IV). Проводять виїзні цикли з будь-якої спеціальності у всі райони Республіки Вірменія за заявками місцевих органів охорони здоров'я [1].

У Вірменії номенклатура лікарських спеціальностей фрормувалася стихійно і не мала жодного наукового та соціально-економічного обґрунтування. Процес розвивався у двох напрямках: 1) як тільки з'являлася якась нова та значима нозологічна фрорма, до неї «приклеювалася» відповідна спеціальність (наприклад, фртизіатрія 3 усіма витікаючими з неї похідними - «фтизіоурологія», «фртизіогінекологія» і т. д., а також негайне дублювання нової спеціальності 3 додатком «дитяча»; 2) при появі нового методу лікування відбувалося те ж саме (наприклад, лікар-мікрохірург, лікар гемодіалізу, лікар-баротерапевт, лікар ультразвукової діагностики і т. д.). Загалом лікарських спеціальностей повинно бути не більше як 40, вони повинні бути затверджені на рівні уряду, число їх повинно бути постійним і зміни в них повинні відбуватися рідко та має бути дуже вагоме обґрунтування, а все решта потрібно віднести до спеціалізації. Кількість спеціальностей може бути необмеженою. Враховуючи, що номенклатура лікарських спеціальностей є базовою первинною ланкою в багаточисельному ланцюгу безперервної медичної освіти, стає зрозумілою вся важливість її якнайшвидшої розробки [13].

Післядипломна медична освіта у Грузії

У Грузії існує Закон про медичну службу. Відповідно до нього кожен лікар повинен мати сертифікат, для того, щоб розпочати або продовжити медичну практику, який оновлюється кожні 5 років. Процедура повторної сертифрікації відбувається з використанням двох можливостей: згромадження визначеної кількості кредитів або проходження іспиту. Для допущення до іспиту, також потрібно мати певну кількість кредитів. Тбіліський медичний університет готує лікарів за американською програмою (USMLE). В університеті діє фракультет загальної медицини з двома програмами навчання: системно-орієн- 
тована та програма, яка базується на вирішенні проблем із комп'ютеризованою системою навчання. Структура програм навчання розроблена спеціально, щоб підвищити результативність та доступність оволодіння навчальним матеріалом. Шестирічна навчальна програма для магістрів розподілена на 3 частини: основні медичні науки (2,5 року), клінічні науки (2,5 року), клінічна практика (1 рік). У 2014 р. уряд Грузії з метою мотивації отримати фрах лікаря призначив державну стипендію для 25 осіб, які навчалися в резидентурі та отримали найвищі бали при складанні кваліфікаційних іспитів у рамках Програми післядипломної медичної освіти. Обов'язковою умовою було те, що вони продовжать роботу в селах та прикордонних районах тим самим вирішивши проблему нестачі кадрів. У 2017 р. уряд призначив такі стипендії 10 резидентам. У процесі післядипломної освіти лікарі, які навчаються як у державних, так і приватних медичних вищих закладах, мають можливість навчатися англійською мовою, використовуючи як англомовні, так і підручники грузинською мовою [23].

Післядипломна медична освіта в Азербайджані

В Азербайджані на сьогодні практично відсутня нова система післядипломної освіти [2]. У цій країні кращі випускники вищих медичних навчальних закладів Азербайджану продовжують післядипломне навчання в США. Спочатку проходять дворічний курс преклінічного навчання, який базується на фрундаментальних науках. Після цього молоді лікарі складають іспит UMSLE 1 рівня, який $є$ необхідним для отримання лікарської ліцензії. Далі один рік вивчають клінічні дисципліни та складають іспит UMSLE 2 рівня, який включає перевірку клінічних знань і навичок. Результати навчання перевіряють за допомогою тестів американської освітньої організації National Board of Medical Education (NBME) [17, 18].

Післядипломна медична освіта у республіках Центральної Азії

Соціальні, політичні та економічні зміни у пострадянських республіках Центральної Азії переживають стан колапсу, що унеможливлює опанування нової системи, яка б мала регіональний характер, і розвивалася за індивідуальними моделями [15].

В Узбекистані на сьогодні використовують німецьку систему післядипломної освіти лікарів. У зв'язку з чим укладено договір про співпрацю 3 товариством міжнародної співпраці та розвитку Німеччини GIZ (Deutsche Gesellschaft für Internationale Zusammenarbeit und nachhaltige Entwicklung $\mathrm{GmbH}$ ). Співпраця існує за такими напрямками: 1) підготовка медичних фрахівців, які працюватимуть на сучасному медичному обладнанні; 2) страхування, обслуговування, поточний ремонт медичного обладнання; 3) планування, фрінансування та забезпечення певних медичних напрямків; 4) узгоджена діяльність громадськості та профресіоналів щодо організації спеціалізованих центрів та тренінгів лікарів [24].

На сьогодні у Киргизькій Республіці залишається проблемним забезпечення кваліфрікованими кадрами первинної медико-санітарної допомоги, особливо в сільських регіонах, що пов'язано із відсутністю надійних механізмів розподілу та збереження кадрів. Неналежні умови для молодих спеціалістів на місцях, а також нерівномірне забезпечення медичним персоналом $є$ наслідком чіткого механізму регулювання процесу найму, кар'єрного зростання, системи винагород та мотивацій. Існує проблема недосконалості нормативно-правової бази, контролю і моніторингу всіх аспектів післядипломної медичної та фрармацевтичної освіти, слабка матеріально-технічна база установ, що впливає на якість підготовки медичних кадрів та їх конкурентоздатність на міжнародному ринку [8, 10].

Казахстан зробив значні кроки на шляху до інтернаціоналізації вищої освіти, вступивши у Болонський процес і прийнявши його стандарти та вимоги [21]. Навантаження викладача включає не тільки навчальні, але і методичні, наукові та виховні години. До основної кількості годин викладача (профресора, доцента, асистента) додаються ті, які він витрачає на наукову діяльність. Існує два типи викладачів - педагог-вихователь та вчитель-дослідник. Але перехід від одного типу викладача до іншого не має чітких критеріїв [20].

Аналізуючи розвиток післядипломної освіти в країнах пострадянського простору звертаємо увагу на те, що в основному всі вони намагаються брати за основу вже існуючі в Європі моделі організації післядипломної освіти лікарів, яких сьогодні нараховується три моделі. Перша сконцентрована на лікареві, тобто фрахових лікарських товариствах та органах лікарського самоврядування. Типовими представниками першої моделі $€$ Німеччина, Австрія, Італія та Чехія, а Велика Британія та Швейцарія - тільки певною мірою. Друга модель ґрунтується на вирішальній ролі державних органів управління охороною здоров'я насамперед Міністерства охорони здоров'я. Така модель працює в Іспанії, Франції та частково в Італії. Третя модель визнає найважливішою роль медичного університету (Україна, Білорусь, Угорщина), який вважається найважливішим у післядипломній медичній освіті, що оцінює знання лікаря та несе за це відповідальність. В Угорщині ця модель є дещо ширшою, оскільки відповідальність за професійну підготовку лікаря несе також і Міністерство охорони здоров'я. Разом із тим, усі ці три моделі мають свої недоліки. Перша модель, у якій домінують лікарські товариства/асоціації, має недолік у великому числі фрахових згромаджень, вимоги яких не унісіковані. Недоліком другої моделі є певне обмеження у прогресивності та нововведеннях і ризик повної комерціалізації лікарської діяльності $[11,14]$. 
Недоліком третьої системи є те, що її розвиток обмежується можливостями державної освітньої системи, проте ризик комерціалізації є дуже низьким. Ідеальна модель на сьогодні все ще не створена [22].

\section{Висновки}

1. Післядипломна медична та фрармацевтична освіта у пострадянських республіках перебуває в стані розбудови та реформування.

2. У розробці нових систем-моделей післядипломної освіти не достатньо враховано національні особливості та традиції країн пострадянського простору та використано далеко не всі можливості загальноприйнятих стандартизованих європейських і світових моделей безперервної медичної та фрармацевтичної освіти.

Перспективою подальших наукових досліджень $€$ створення власної моделі безперервної медичної та фрармацевтичної освіти з врахуванням світового досвіду та потреб українських споживачів.

\section{Список літератури}

1. Авакян М. Н. Об опыте организации непрерывного медицинского образования в Республике Армения [Электронный ресурс] / М.Н.Авакян, Г.В.Ягджян // Журнал сообщества медицинских преподавателей. - 2012. № 4 (10). - С. 1-12. - Режим доступа : http://www.med-practic.com/rus/609/31304/article.more.html

2. Алиева С. Н. О путях оптимизации системы высшего образования / С. Н. Алиева // Вектор науки ТГУ. - 2011. T. 4, № 7. - C. 21-23.

3. Вилюнас В. К. Психологические механизмы мотивации человека / В. К. Вилюнас. - М., 1990. -288 с.

4. Вязьмин А. М. Подготовка руководителей здравоохранения и специалистов для сектора общественного здравоохранения в рамках системы непрерывного медицинского образования в Российской Федерации / А. М. Вязьмин, М. В. Щавелева // Вопросы организации и инфрорматизации здравоохранения. - 2015. - № 2. - С. 67-73.

5. Горшунова Н. К. Соответствие международным критериям и особенности отечественного образовательного стандарта послевузовской профессиональной подготовки специалистов по общей врачебной практике/семейной медицине / Н. К. Горшунова // Современные проблемы науки и образования. - 2006. - № 4. - С. 34-37.

6. Демидчик Ю. Е. Последипломное образование в Республике Беларусь [Электронный ресурс] / Ю. Е. Демидчик, А. И. Кушнеров, И. В. Ганкова-Дуган // Тherapia - Украинский медицинский вестник. - 2015. - С. 1-4. - Режим доступа : http://therapia.ua/therapia/2013-/3-78/poslediplomnoe-obrazovanie-vrespublike-belarus

7. Думанян Д. Г. Последипломное медицинское образование: теоретические и методологические аспекты / Д. Г. Думанян, Н. А. Симонян // Армянский медицинский журнал. - 2003. - № 2. - С. 103-111.

8. Концепция развития последипломного образования в Кыргызской Республике (проект) [Электронный ресурс]. Бишкек, 2011. - С. 1-21. - Режим доступа : http://mognovse.ru/ebd-koncepciya-razvitiya-poslediplomnogo-obrazovaniyav-kirgiz.html

9. Кульпанович О. А. Последипломная подготовка врачей в Беларуси [Электронный ресурс] / О. А. Кульпанович // Здравоохранение. - 2010. - № 1. - С. 77-80. - Режим доступа : http://www.zdrav.by/poslediplomnaya-podgotovkavrachey-belarusi

10. Леонтьев А. Н. Деятельность. Сознание. Личность / А. Н. Леонтьев. - М. : Политиздат, 1975. - 304 с.

11. Маслоу А. Самоактуализация. Психология личности / А. Маслоу. - М., 1982. - С. 108-117.

12. Мошетова Л. К. Непрерывное профессиональное образование врачей в Российской медицинской академии последипломного образования [Электронный ресурс]/Л. К. Мошетова// Федеральный справочник «Здравоохранение России». - 2014. - № 15. - С. 288-294. - Режим доступа : Z15:verstka-sbor-3110-sp.indd

13. Ованесян P. А. Проблемы непрерывного медицинского образования в Республике Армения и пути их разрешения / Р. А. Ованесян // Армянский медицинский рефреративный журнал. - 2003. - № 2. - С. 92-99.

14. Пономарев Я. А. Психология творчества / Я. А. Пономарев. - М. : Наука, 1974. - 304 с.

15. Профрессиональная подготовка врачей-психиатров в странах Восточно-Европейской зоны WPA: проблемы и решения / П. В. Морозов, У. Х. Алимов, 3. Ш. Амуров [и др.] // Український вісник психоневрології. - 2015. - Т. 23, № 84. - Вип. 3. - С. 16-21.

16. E-learning in medical education in resource constrained low- and middle-income countries / S. Frehywot, V. Vovides, Z. Talib [et al.] // Human Resources for Health. - 2013. - Vol. 11, No. 4. - P. 3-15.

17. Azari F. S. The experiences of an Azerbaijani student to attainment of medical education in United States: From Baku to Charlottesville / F. S. Azari // AMAJ. - 2016. - Vol. 3. - P. 65-69.

18. Central Asian republics: A case study for medical education reform / K. A. Conaboy, Zh. Nugmanova, S. Yeguebaeva [et al.] // The Journal of Continuing Education in the Health Professions. - 2005. - Vol. 25. - P. 52-64.

19. Jargin S. V. Some aspects of medical education in Russia / S. V. Jargin // American Journal of Medicine Studies. 2013. - Vol. 1, No. 2. - P. 4-7. Electronic source: DOI: 10.12691/ajms-1-2-1

20. Massakova S. S. Modernization of higher education and its impact on academic and teaching activity / S. S. Massakova // The Way of Science. - 2014. - No. 4. - P. 104-107. Electronic source: https://translate.googleusercontent.com/translate_f 21. Monobayeva A. Internationalization of higher and posthraduate education in Kazakhstan: focus on business education / A. Monobayeva // International Journal of Business and Government Studies. - 2013. - Vol. 5, No. 1. - P. $2146-0744$.

22. Schaffer $M$. Beyong accreditation systems - the identification of different implementation models for CME across Europe / M. Schaffer, I. Weisshardt // Journal of European CME. - 2013. - Vol. 2. - P. 5-9.

23. Sumbadze Nana. Public Health Management and Policy Education and Training: Georgia. / Sumbadze Nana, Khatuna Dolidze // Health Care Delivery Systems. Bratislava: NISPAceel; 2004. - 29 p. 
24. Varela M. Activity report of GIZ project "Advanced training of doctors and medical staff to work on modern high-tech medical equipment in Uzbekistan" / M. Varela, D. Billard // 2014. - P. 1-25. https://www.giz.de/en/downloads/giz2013-enlife-cycle-cost-project-study-report-uzbekistan.pdf

\section{References}

1. Avakyan, M.N., \& Yagdzhyan, G.V. (2012). Ob opyte organizatsii nepreryvnogo meditsinskogo obrazovaniya v Respublike Armeniya [On the experience of the organization of continuous medical education in the Republic of Armenia]. Zhurnal soobshchestva meditsinskikh prepodavateley - Journal of the Community of Medical Teachers, 4 (10), 1-12. Retrieved from: http://www.med-practic.com/rus/609/31304/article.more.html [in Russian].

2. Aliyeva, S.N. (2011). O putyakh optimizatsii sistemy vysshego obrazovaniya [About ways of optimization of system of higher education]. Vektor nauki TGU - Vector of Science TSU, 4 (7), 21-23 [in Russian].

3. Vilyunas, V.K. (1990). Psikhologicheskiye mekhanizmy motivatsii cheloveka [Psychological mechanisms of human motivation]. Moscow [in Russian].

4. Vyazmin, A.M., \& Shaveleva, M.V. (2015). Podgotovka rukovoditeley zdravookhraneniya i spetsialistov dlya sektora obshchestvennogo zdravookhraneniya $v$ ramkakh sistemy nepreryvnogo meditsinskogo obrazovaniya $v$ Rossiyskoy Federatsii [Training of health managers and specialists for the public health sector within the framework of the system of continuous medical education in the Russian Federation]. Voprosy organizatsii i informatizatsii zdravookhraneniya Issues of Health Organization and Informatization, 2, 67-73 [in Russian].

5. Gorshunova, N.K. (2006). Sootvetstviye mezhdunarodnym kriteriyam i osobennosti otechestvennogo obrazovatelnogo standarta poslevuzovskoy professionalnoy podgotovki spetsialistov po obshchey vrachebnoy praktike/semeynoy meditsine [Conformity to international criteria and features of the national educational standard of postgraduate professional training of specialists in general medical practice/family medicine]. Sovremennyye problemy nauki i obrazovaniya - Modern Problems of Science and Education, 4, 34-37 [in Russian].

6. Demidchik, Yu.E., Kushnerov, A.I., \& Gankova-Dugan, I.V. (2015). Poslediplomnoye obrazovaniye v Respublike Belarus [Postgraduate education in the Republic of Belarus]. Therapia - Ukrainskiy meditsinskiy vestnik - Therapia - Ukrainian Medical Herald, 1-4. Retrieved from: http://therapia.ua/therapia/2013-/3-78/poslediplomnoe-obrazovanie-vrespublikebelarus [in Russian].

7. Dumanyan, D.G., \& Simonyan, N.A. (2003). Poslediplomnoye meditsinskoye obrazovaniye: teoreticheskiye i metodologicheskiye aspekty [Postgraduate medical education: theoretical and methodological aspects]. Armyanskiy meditsinskiy zhurnal - Armenian Medical Journal, 2, 103-111 [in Russian].

8. (2011). Kontseptsiya razvitiya poslediplomnogo obrazovaniya v Kyrgyzskoy Respublike (proekt) [The concept of development of postgraduate education in the Kyrgyz Republic (project)]. Bishkek. - Retrieved from: http://mognovse.ru/ ebd-koncepciya-razvitiya-poslediplomnogo-obrazovaniya-v-kirgiz.html

9. Kulpanovich, O.A. (2010). Poslediplomnaya podgotovka vrachey v Belarusi [Postgraduate training of doctors in Belarus]. Zdravookhraneniye - Health Care, 1, 77-80. Retrieved from: http://www.zdrav.by/poslediplomnaya-podgotovka-vracheybelarusi

10. Leontev, A.N. (1975). Deyatelnost. Soznaniye. Lichnost [Activity. Consciousness. Personality]. Moscow: Politizdat [in Russian].

11. Maslov, A. (1982). Samoaktualizatsiya. Psikhologiya lichnosti [Self-actualization. Psychology of Personality]. Moscow [in Russian].

12. Moshetova, L.K. (2014). Nepreryvnoye professionalnoye obrazovaniye vrachey v Rossiyskoy meditsinskoy akademii poslediplomnogo obrazovaniya [Continuous professional education of doctors in the Russian Medical Academy of Postgraduate Education]. Federalnyy spravochnik "Zdravookhraneniye Rossii" - Federal Directory "Health Care in Russia", 15, 288-294. Retrieved from: Z15:verstka-sbor-3110-sp.indd [in Russian].

13. Ovanesyan, R.A. (2003). Problemy nepreryvnogo meditsinskogo obrazovaniya v Respublike Armeniya i puti ikh razresheniya [Problems of continuing medical education in the Republic of Armenia and ways to resolve them]. Armyanskiy meditsinskiy referativnyy zhurnal - The Armenian Medical Abstract Journal, 2, 92-99 [in Russian].

14. Ponomarev, I.A. (1974). Psikhologiya tvorchestva [Psychology of creativity]. Moscow: Nauka [in Russian].

15. Morozov, P.V., Alimov, U.H., Amurov, Z.Sh. (2015). Professionalnaya podgotovka vrachey-psikhiatrov $v$ stranakh Vostochno-Yevropeyskoy zony WPA: problemy i resheniya [Training of psychiatrists in the countries of the Eastern European Area WPA: problems and solutions]. Ukrayins'kyy visnyk psykhonevrolohiyi - Ukrainian Journal of Psychoneurology, 23 (84), 3, 16-21.

16. Frehywot, S., Vovides, V., Talib, Z., Mikhail, N., Ross, H., Wohltjen, H., Bedada, S., Korhumel, K., Koumare, A.K., Scott, J. (2013). E-learning in medical education in resource constrained low- and middle-income countries. Human Resources for Health, 11 (4), 3-15.

17. Azari, F.S. (2016). The Experiences of an Azerbaijani Student to Attainment of Medical Education in United States: From Baku to Charlottesville. AMAJ, 3, 65-69.

18. Conaboy, K.A., Nugmanova, Zh., Yeguebaeva, S., Jaeger, F., Daugherty, R.M. (2005). Central Asian republics: A case study for medical education reform. The Journal of Continuing Education in the Health Professions, 25, 52-64.

19. Jargin, S.V. (2013). Some aspects of medical education in Russia. American Journal of Medicine Studies, 1(2), 4-7. DOI: 10.12691/ajms-1-2-1

20. Massakova, S.S. (2014), Modernization of higher education and its impact on academic and teaching activity. The Way of Science, 4 (4), 104-107. Retrieved from: https://translate.googleusercontent.com/translate_f

21. Monobayeva, A. (2013). Internationalization of higher and posthraduate education in Kazakhstan: focus on business education. International Journal of Business and Government Studies, 5 (1), 2146-0744. 
22. Schaffer, M., \& Weisshardt, I. (2013). Beyong accreditation systems - the identification of different implementation models for CME across Europe. Journal of European CME, 2, 5-9.

23. Sumbadze Nana, \& Khatuna Dolidze. (2004). Public Health Management and Policy Education and Training: Georgia. Public Health Administration, Management and Policy. In: Rosenbaum A, Nemec J, and Tolo K. Health Care Delivery Systems. Bratislava: NISPAcee, 29.

24. Varela, M., \& Billard, D. (2014). Activity report of GIZ project "Advanced training of doctors and medical staff to work on modern high-tech medical equipment in Uzbekistan" 1-25. - Retrieved from: https://www.giz.de/en/downloads/giz2013-enlife-cycle-cost-project-study-report-uzbekistan.pdf

\section{ОСОБЕННОСТИ ПОСЛЕДИПЛОМНОГО ОБРАЗОВАНИЯ СТРАН ПОСТСОВЕТСКОГО ПРОСТРАНСТВА}

О.Е. Сичкориз

Львовский национальный медицинский университет имени Данила Галицкого, г. Львов, Украина

Цель: анализ особенностей становления медицинского и фармацевтического последипломного образования в странах постсоветского пространства.

Материалы и методы. В работе проведен ретроспективный анализ развития последипломного образования в постсоветском пространстве. Для разбора использовано аналитико-описательный метод изучения и обобщения теории и опыта обучения в высших учебных заведениях, критический анализ научной литературы по педагогике и методике обучения по теме исследования.

Результаты. В работе обозначены основные этапы развития последипломного образования в постсоветских странах, освещена разница последипломного медицинского образования в России и в других государствах на сегодня и проведено сравнение их с международными и европейскими моделями. Показано, что последипломное медицинское и фрармацевтическое образование в постсоветских республиках находится в состоянии развития и реформирования.

Выводы. В разработке новых систем-моделей последипломного образования недостаточно учтены национальные особенности и традиции стран постсоветского пространства и использованы далеко не все возможности общепринятых стандартизированных европейских и мировых моделей непрерывного медицинского и фрармацевтического образования.

КЛЮЧЕВЫЕ СЛОВА: последипломное медицинское образование; постсоветские страны; европейские модели образования; повышение квалификации.

\section{PECULIARITIES OF POST-GRADUATE EDUCATION IN COUNTRIES OF FORMER SOVIET UNION}

O.Y. Sichkoriz

Danylo Halytskyi Lviv National Medical University, Lviv, Ukraine

Purpose: to analyze developmental peculiarities of medical and pharmaceutical post-graduate education in countries of former Soviet Union.

Materials and Methods. The paper presents the results of retrospective analysis of the development of post-graduate education in countries of former Soviet Union. The study involved the application of analytical and descriptive research methods for analyzing and generalization of both learning theory and experience at higher education institutions; critical analysis of scientific literature on pedagogy; learning and teaching methodology by the theme of the research.

Results and Discussion. This study defines the main developmental stages of post-graduate education in countries of former Soviet Union; highlights the differences between current post-graduate education in Russia and other countries; presents the results of their comparison with international and European models. It has been determined that a post-graduate education in countries of former Soviet Union is on the stage of its development and reformation.

Conclusions. The designing process of new system-models of post-graduate education lacks sufficient consideration of national features and traditions of countries of former Soviet Union. Moreover, hardly any possibilities of generally accepted standardized European and World models of continuous medical and pharmaceutical education were used.

KEY WORDS: post-graduate medical education; countries of former Soviet Union; European educational models; post-graduate qualification-based training.

Рукопис надійшов до редакції 22.03.2018 p.

\section{Відомості про автора:}

Січкоріз Орест Євгенович - кандидат медичних наук, доцент кафедри дитячих інфекційних хвороб, декан фракультету післядипломної освіти Львівського національного медичного університету імені Данила Галицького; тел.: +38(032) 276-93-74; +38(050) 317-15-54. 